CARPATHIAN JOURNAL OF FOOD SCIENCE AND TECHNOLOGY

journal homepage: http://chimie-biologie.ubm.ro/carpathian_journal/index.html

\title{
SENSORY ATTRIBUTES PROFILING OF DAMPIT ROBUSTA COFFEE LEAF TEA (Coffea canephora)
}

\author{
Sudarminto Setyo Yuwono ${ }^{1}$, Kiki Fibrianto ${ }^{1 *}$, Laila Yum Wahibah ${ }^{1}$, Aswin Rizky Wardhana ${ }^{1}$ \\ ${ }^{1}$ Sensory and Applied Food Science Research Group, Faculty of Agricultural Technology, Universitas \\ Brawijaya, Malang, Indonesia \\ *kiki.fibrianto@ub.ac.id
}

https://doi.org/10.34302/crpjfst/2019.11.2.13

\begin{tabular}{ll}
\hline $\begin{array}{l}\text { Article history: } \\
\text { Received: }\end{array}$ & $\begin{array}{l}\text { ABSTRACT } \\
\text { 14 January 2019 }\end{array}$ \\
$\begin{array}{l}\text { Abundant leaf waste resulted from the maintenance of coffee plants can } \\
\text { alternatively be made into coffee leaf tea. The results of this study indicate } \\
\text { 29 May 2019 }\end{array}$ & $\begin{array}{l}\text { that old Robusta coffee leaf significantly have increasing total phenol, pH } \\
\text { and color, but decreasing the level of caffeine. The fermentation process }\end{array}$ \\
can significantly reduce total phenol, caffeine content, pH and color. \\
Keywords: & Meanwhile, the brewing temperature only gives a real effect on the color of \\
Coffee leaf tea; & steeping tea. Based on the method of Rate-All-that-Apply (RATA), coffee \\
Fermentation; & leaf tea powder has aroma characteristics (green, wood, floral, earth and \\
Leaf age; & sweet), while the steeping tea has characteristics of having green aroma \\
Serving temperature; & and flavor as well as bitter taste and astringent in mouth. The most \\
& dominant profile of aromatic compounds of coffee leaf tea with GCMS \\
& HS-SPME method is green which might be attributed by 2-heptanol \\
& (CAS), 2-hexen-1-ol, 1-furfuryl-2-formyl pyrrole, safranal, beta- \\
& cyclocitral, 4-heptanal,(Z)-(CAS), hexanal (CAS), nonanal, \\
benzeneacetaldehyde, benzaldehyde, 2-heptanone (CAS).
\end{tabular}

\section{Introduction}

Coffee is one of the most widely consumed beverages worldwide, due to its distinctive flavor and aroma (Campanha et al., 2009). Brazil, Vietnam, Colombia and Indonesia are the main coffee producing countries because they are located in suitable areas to grow (WBCM and ICO, 2017). Coffee plants will be trimmed regularly because it can grow up to 1.5 - 4.6 meters. Pruning is needed to optimize fruit production and plant maintenance (Jonathan et al., 2009). However, pruning produces abundant waste in the form of coffee leaves that are not utilized in large quantities. Therefore, it is necessary to find out alternative use of coffee leaves.
One alternative use of coffee leaves is using them as a material for making tea. Coffee leaf tea is one of Indonesia's typical drinks, precisely derived from the realm of Minang in Padang, West Sumatra (Ratanamarno and Subskar, 2017). During the Dutch colonial period of 1847-1908, the population of West Sumatra Minangkabau experienced a system of colonial exploitation in the system of forced cultivation. Residents had to submit all the coffee beans cultivated to the Dutch, so people who wanted to enjoy coffee could only use the coffee leaves for beverages. Drinks from the coffee leaves are known as "Kopi Daawa Melayu or "Kopi Kawa" (Akira, 1977 in Booth et al., 1988). 
Ratanamarno and Surbkar (2017) suggest that the differences of leaf age, the pretreatment, and brewing time, affecting the differences on caffeine and catechin contents of Arabica leaf tea (Coffea arabica). Young and non-fermented coffee leaves tent to have hinger levels of caffeine and catechins than those of old leaves. They also suggest that the recommend brewing time is 5 minute, to minimize caffeine level. According to Yitayal and Achame (2015) revealed the effects of caffeine on a mixture of coffee leaves and spices that are processed differently by Roasted, Raw and Majengir. The caffeine content of the Roasted type was not significantly different from Majengir type in both solvents. Tea mixed coffee leaves and spices can be used as an alternative to coffee drinks that are low in caffeine in Ethiophia. In further research (Yitayal and Titalun, 2017) reported the nutritional value of coffee leaf tea in the form of proximate and mineral composition. Coffee leaf tea contains essential and vital nutrients for energy and health, so this drink can be used to meet the nutritional needs of the community.

It shows that coffee leaf tea can have health effects because they contain caffeine and polyphenols, but for some people caffeine can lead to increase heart rate, at risk of cholesterol buildup (Hoeger et al., 2001), stomach disorders, anxiety, diminished memory, and insomnia. The caffeine content also affects bitter flavor correlated with other bitter tasteforming compounds such as alcohol, caffeine, trigonelline and guinine, and correlated with chlorogenic acid, polyphenols, catechins and other compounds (Calvert et al., 2015).

This study aims to introduce the coffee leaf tea as a traditional drink from Sumatra Indonesia, focusing on profiling sensory attributes. This study also aims to determine the effect of leaf age, the process of manufacture, and temperature of serving on the physicochemical, sensory and aromatic compounds.

\section{Materials and methods}

\subsection{Tea Samples and Physicochemical Analysis}

Coffee leaves were harvested from Robusta coffee plants (Coffea canephora), growing under natural environment in Dampit, Malang, Indonesia. Young leaves were picked from bud to the 4th leaves, while old leaves were picked from the 5th to 8th leaves. The chemicals and reagents used consisted of folin-ciocalteu's phenol reagent and gallic acid for phenol total (Spectrophotometry), sugar total (refractometer), petroleum eter for fat content (soxhlet), indicator fenolpthhalein and $\mathrm{NaOH}$ for total acid (titration), and buffer $\mathrm{pH} 4$ and $\mathrm{pH} 7$ for $\mathrm{pH}$ measurement ( $\mathrm{pH}$ meter).

\subsection{Coffee Leaf Tea Processing}

Non-fermentation method: young or old coffee leaves were washed and cut into small pieces, after that dried with an electric oven at the temperature of $70 \pm 2{ }^{\circ} \mathrm{C}$ for 4 hours. As for the method of fermentation: young or old coffee leaves were washed and cut into small pieces, then withered and rolled at room temperature of $23-27{ }^{\circ} \mathrm{C}$ for $18-24$ hours, followed by drying with an electric oven at the temperature of $70 \pm 2{ }^{\circ} \mathrm{C}$ for 4 hours. The 4 samples of dried coffee leaf tea were ground using a blender at $3000 \mathrm{rpm}$ and $3 \pm 1$ minute duration, then they were divided into small plastic clips and given a three-digit random code of 2 grams per bag. Samples of dried coffee leaf tea were brewed with hot water at $90-96{ }^{\circ} \mathrm{C}$. Then each sample was presented in 3 different serving temperatures i.e. cold temperatures ranging from $8-12{ }^{\circ} \mathrm{C}$, normal temperature of $23-27^{\circ} \mathrm{C}$, and warm temperature of $40-44^{\circ} \mathrm{C}$.

\subsection{Phenol Total Analysis}

Phenol total analysis followed Pal et al., (2012). The $1 \mathrm{ml}$ sample was diluted with 
distilled water at a ratio of $1: 10$. The mixture was placed on the test tube, and $1 \mathrm{ml}$ ethanol was added. $5 \mathrm{ml}$ of distilled water and $0.5 \mathrm{ml}$ of the Folin-Ciocalteu reagent $(50 \%)$ were added to the test tube and mixed. After 5 minutes, 1 $\mathrm{ml}$ of $\mathrm{Na}_{2} \mathrm{CO}_{3}(10 \%)$ was added in the tube and mixed until homogeny. The mixture was then placed in a darkened room or covered with aluminum foil for 60 minutes. After that, the absorbance was measured with a wavelength of $725 \mathrm{~nm}$. The standard curve was made in the same way by replacing the sample with an error acid made with some concentration. Total polyphenol content in tea functional drinks was expressed in $\mathrm{mg} / \mathrm{L}$.

\subsection{Caffeine Analysis}

Caffeine stock solution (1000 ppm) was prepared in distilled water. Different working solutions were prepared by serial dilution with the addition of $1.0 \mathrm{ml}$ hydrochloric acid. The $0.25 \mathrm{~g}$ sample was weighed and diluted accurately in water and prepared with a net volume of $20 \mathrm{ml}$ with distilled water. The 20 $\mathrm{ml}$ sample solution was pipetted in a $250 \mathrm{ml}$ flask and $10 \mathrm{ml}$ of $0.01 \mathrm{~mol} / \mathrm{l}$ hydrochloric acid and $2 \mathrm{ml}$ acetic acid solution were then added. The final volume was prepared with distilled water. The $50 \mathrm{ml}$ solution was filtered and added to a $100 \mathrm{ml}$ flask. $0.2 \mathrm{ml}$ of 4.5 moles of sulfuric acid was added and again made to a clean and filtered volume. The absorption of work standards and samples was measured on the UV/Vis (Shimadzu) spectrophotometer. The level of caffeine from the sample was calculated through the regression equation of the best line according to the standard (Christian, 1994).

\subsection{Volatile Compounds Evaluation}

Analysis of volatile compounds in coffee leaf tea was done by GCMS (Gas Chromatography Mass Spectrometry) and SPME (Solid Phase Micro Extraction) 4000 variant of GCMS (Variant, Inc., USA) consisting of $3,800 \mathrm{GC}$ with $\mathrm{CP}-8410$ auto injector (Bruker, USA), and 4,000 Ion Traps
MS detector with CP-1177 split/spitkess injectors, at a temperature of $300{ }^{\circ} \mathrm{C}$ and a 1.0 $\mu \mathrm{L}$ injection volume. Each splitless mode: Agilent focus liner with glass wool deactivation was done in triplicate Manually Chromatographic. Separation was done by using Zebron MultiResidue-1 columns (30 m × $0.25 \mathrm{~mm}$ x $0.25 \mu \mathrm{m}$; Phenomenex Inc., USA); internal diameter $\times 0.25 \mu \mathrm{m}$; film thickness) capillary column (Restek, Bellefonte, PA, USA) (Lee et al., 2013).

\subsection{Sensory Analysis}

Sensory analysis was used the RATA (RateAll-that-Apply) method with two stages, namely to know the characteristics of powder sensory and coffee leaf tea steeping. The panelists were used untrained panelists of 110 people, who consisted of men and women with an age ranging from 18 to 45 years. The main instrument was used the RATA questionnaire with scores 1-3 to describe the sample of sensory characteristics, i.e. score 1 for low intensity attributes, score 2 for moderate intensity attributes, and score 3 for high intensity attributes. Sensory attributes that do not describe sensory characteristics need not be ticked (Ares et al., 2014).

\subsection{Data Analysis}

The sensory intensity attributes responding on leaf age factor, pre-treatment, and serving temperature were analyzed using GLM (General Linear Model). In addition, GLM was used to find out the results of chemical and physical tests on samples with different factors. The datas were analyzed using statistical analysis program MiniTab 17.

\section{Results and discussions}

\subsection{Characteristics of Coffee Leaf Tea}

Table 1 shows that the various leaf ages of the processing stage gives significant difference ( $\mathrm{p}<0.05)$ to water content, ash content, fat content, total sugar, total acid, reddish color intensity $(\mathrm{a}+)$ and yellowish $(\mathrm{b}+)$, but not 
significant ( $\mathrm{p}>0.05)$ for brightness intensity ( $\mathrm{L}$ $*$ ).

Young leaf tea in Table 1 tends to have higher water content than old leaf tea, because the older the age of the leaves the more decreasing the water content. Young leaves have a relatively soft texture, because they have more moisture content than old leaves (Osman et al., 2004). Fermentation of the old leaves causes a difference in water content which increases along with the longer fermentation time. This is due to the oxidative fermentation reaction of catechins with oxygen to produce water vapor and result in increased water content (Bradley and Vanderwam, 2001).

When the water content $\left(\mathrm{H}_{2} \mathrm{O}\right)$ in the material increases, the ash content decreases. Thus, the ash content on old leaves decreases with the fermentation process. This is as a result of the abundance of water-soluble minerals and fats, so it will come together during the drying process. Decrease of the ash content can occur because of during the fermentation process there will be an increase in organic material due to the degradation of substrate by microbes. The less organic matterdegradation, the less decrease of ash content (Hatakka, 2001).

In old coffee leaf tea, the fat content tends to be higher in Table 1 because the moisture content of the leaves is lower. During the drying process there has been decomposition of the water molecule bonding component $\mathrm{H}_{2} \mathrm{O}$ and increasing the sugar, fat, minerals and protein content, there by rising the ash content. In addition, the decrease in the fat content is caused by the degradation of lipase enzyme (Bhara, 2009).

Sucrose is a disaccharide found in plants, included in non-reducing sugars because the active groups are already bonded to each other. Sweet-tasting components such as sugar, aldehydes, sulphide and benzoate emerge during the fermentation. Reduced sugar content will increase due to sucrose hydrolysis to glucose by invertase enzyme. The decrease in total sugar in Table 1 and the drying process breaks down the water molecule bond component $\left(\mathrm{H}_{2} \mathrm{O}\right)$ and increases the sugar content (Bhara, 2009).

Coffee leaf tea has caffeine content which will evaporate when drying or roasting, forming components such as acetone, furfural, ammonia, trimethylamin, formic acid and acetic acid (Khan and Mukhtar, 2007). The longer the fermentation, the more the acidity of coffee leaves as described in Table 1. This is because of the formation of aliphatic acids during fermentation. If the fermentation is extended, there will be aliphatic chemical composition changes to esters of carboxylic acids resulting in the taste of rottenness (Famwort, 2005).

Table 1. Physical characteristics of coffee leaf tea powder

\begin{tabular}{|l|c|c|c|c|c|c|c|c|}
\hline Sample & $\begin{array}{c}\text { Water } \\
\text { Content (\%) }\end{array}$ & $\begin{array}{c}\text { Ash Content } \\
(\boldsymbol{\%})\end{array}$ & $\begin{array}{c}\text { Fat Content } \\
(\boldsymbol{\%})\end{array}$ & $\begin{array}{c}\text { Total } \\
\text { Sugar (\%) }\end{array}$ & $\begin{array}{c}\text { Total Acid } \\
(\boldsymbol{\%})\end{array}$ & $\mathbf{L}^{*}$ & a+ & b+ \\
\hline MNF & $10.57^{\mathrm{a}}$ & $5.01^{\mathrm{d}}$ & $1.23^{\mathrm{c}}$ & $0.61^{\mathrm{d}}$ & $2.11^{\mathrm{b}}$ & $41.90^{\mathrm{a}}$ & $2.73^{\mathrm{a}}$ & $9.77^{\mathrm{b}}$ \\
\hline MF & $10.56^{\mathrm{a}}$ & $5.29^{\mathrm{c}}$ & $0.82^{\mathrm{d}}$ & $4.17^{\mathrm{b}}$ & $2.85^{\mathrm{a}}$ & $42.93^{\mathrm{a}}$ & $2.87^{\mathrm{a}}$ & $10.70^{\mathrm{a}}$ \\
\hline TNF & $6.73^{\mathrm{b}}$ & $6.51^{\mathrm{a}}$ & $4.28^{\mathrm{a}}$ & $0.80^{\mathrm{c}}$ & $1.87^{\mathrm{c}}$ & $43.40^{\mathrm{a}}$ & $1.90^{\mathrm{ab}}$ & $11.00^{\mathrm{a}}$ \\
\hline TF & $6.83^{\mathrm{b}}$ & $6.10^{\mathrm{b}}$ & $3.22^{\mathrm{b}}$ & $4.37^{\mathrm{a}}$ & $2.87^{\mathrm{a}}$ & $42.87^{\mathrm{a}}$ & $1.03^{\mathrm{b}}$ & $9.07^{\mathrm{b}}$ \\
\hline
\end{tabular}

Note: (MNF) young leaf with a non fermented method; (MF) young leaf with a fermentation method; (TNF) old leaf with a non fermented method; (TF) old leaf with a fermented method; $\left({ }^{\mathrm{a}, \mathrm{b}, \mathrm{c}, \mathrm{d}}\right)$ notation of real difference with Tukey statistics $(\mathrm{p}<0,05)$ 
Table 2. Physicochemical characteristics of coffee leaf tea

\begin{tabular}{|l|l|c|c|c|c|c|c|}
\hline \multirow{2}{*}{ Factor } & Treatment & $\begin{array}{c}\text { Phenol Total } \\
\text { mgGAE/g }\end{array}$ & $\begin{array}{c}\text { Caffeine } \\
(\boldsymbol{\%})\end{array}$ & $\mathbf{p H}$ & $\mathbf{L}^{*}$ & $\mathbf{a +}$ & $\mathbf{b +}$ \\
\hline Leaf Age & Young Leaf & $67.76^{\mathrm{b}}$ & $0.56^{\mathrm{a}}$ & $5.66^{\mathrm{b}}$ & $29.67^{\mathrm{b}}$ & $2.82^{\mathrm{b}}$ & $5.27^{\mathrm{b}}$ \\
\hline & Old Leaf & $78.77^{\mathrm{a}}$ & $0.52^{\mathrm{b}}$ & $5.77^{\mathrm{a}}$ & $32.14^{\mathrm{a}}$ & $3.42^{\mathrm{a}}$ & $10.39^{\mathrm{a}}$ \\
\hline Process & Non Fermented & $75.23^{\mathrm{a}}$ & $0.55^{\mathrm{a}}$ & $5.73^{\mathrm{a}}$ & $32.34^{\mathrm{a}}$ & $4.53^{\mathrm{a}}$ & $10.06^{\mathrm{a}}$ \\
\hline & Fermented & $71.31^{\mathrm{b}}$ & $0.53^{\mathrm{b}}$ & $5.69^{\mathrm{b}}$ & $29.47^{\mathrm{b}}$ & $1.70^{\mathrm{b}}$ & $5.61^{\mathrm{b}}$ \\
\hline \multirow{4}{*}{$\begin{array}{l}\text { Temperature } \\
\text { of serving }\end{array}$} & Cold & $73.11^{\mathrm{a}}$ & $0.54^{\mathrm{a}}$ & $5.69^{\mathrm{a}}$ & $31.03^{\mathrm{a}}$ & $3.19^{\mathrm{b}}$ & $8.62^{\mathrm{a}}$ \\
\cline { 2 - 8 } & Room & $73.96^{\mathrm{a}}$ & $0.53^{\mathrm{a}}$ & $5.72^{\mathrm{a}}$ & $32.92^{\mathrm{a}}$ & $4.32^{\mathrm{a}}$ & $9.73^{\mathrm{a}}$ \\
\cline { 2 - 8 } & Warm & $72,73^{\mathrm{a}}$ & $0,53^{\mathrm{a}}$ & $5,73^{\mathrm{a}}$ & $28,77^{\mathrm{b}}$ & $1,83^{\mathrm{b}}$ & $5,14^{\mathrm{b}}$ \\
\hline
\end{tabular}

$\left({ }^{a, b, c, d}\right)$ notation of significant difference with Turkey statistics $(\mathrm{p}<0,05)$

Table 3. Volatile components of coffee leaf tea analyzed with GCMS HS-SPME

\begin{tabular}{|c|c|c|c|c|c|c|}
\hline No & Compound & MNF & MF & TNF & TF & Aroma Description \\
\hline 1 & $\begin{array}{l}\text { (methyl benzoate) Benzoic acid, 2- } \\
\text { (acetyloxy), methyl ester (CAS) }\end{array}$ & $\sqrt{ }$ & & & $\sqrt{ }$ & fragrant, fruity \\
\hline 2 & 2-furanmethanol (CAS) & $\sqrt{ }$ & & $\sqrt{ }$ & & caramellic, coffee, bready, sweet, burnt, brown \\
\hline 3 & 2-heptanol (CAS) & $\sqrt{ }$ & $\sqrt{ }$ & & $\sqrt{ }$ & $\begin{array}{l}\text { fresh, herbal, sweet, floral, green, fruity, green, } \\
\text { earthy }\end{array}$ \\
\hline 4 & Linalool & $\sqrt{ }$ & $\sqrt{ }$ & $\sqrt{ }$ & $\sqrt{ }$ & fruity, floral, rose-like \\
\hline 5 & Phytol & $\sqrt{ }$ & $\sqrt{ }$ & $\sqrt{ }$ & $\sqrt{ }$ & floral, oily, balsamic, herbal, magnolia, orchid \\
\hline 6 & 2-Hexen-1-ol & $\sqrt{ }$ & & & $\sqrt{ }$ & fresh, fruity, green, grassy \\
\hline 7 & 1-Hexanol,2-ethyl- (CAS) & $\sqrt{ }$ & $\sqrt{ }$ & $\sqrt{ }$ & $\sqrt{ }$ & newly cut grass \\
\hline 8 & 1-Furfuryl-2-formyl pyrrole & $\sqrt{ }$ & & & $\sqrt{ }$ & roasted, chocolaty and green \\
\hline 9 & $\begin{array}{l}\text { (Safranal)1,3-Cyclohexadiene- } \\
\text { 1carboxaldehyde,2,6,6trimethyl(CAS) }\end{array}$ & $\sqrt{ }$ & $\sqrt{ }$ & $\sqrt{ }$ & $\sqrt{ }$ & $\begin{array}{l}\text { herbal, woody, sweet, green floral, herbaceous, } \\
\text { somewhat tobacco }\end{array}$ \\
\hline 10 & Beta-Cyclocitral & $\sqrt{ }$ & $\sqrt{ }$ & & & minty, herbal, rose, green, fruity, tea \\
\hline 11 & 4-heptanal,(Z)-(CAS) & $\sqrt{ }$ & & $\sqrt{ }$ & & green, biscuit, cream, fat, fishy, rotten \\
\hline 12 & 2,4-heptadienal & $\sqrt{ }$ & $\sqrt{ }$ & $\sqrt{ }$ & $\sqrt{ }$ & fatty, nutty, hay, fishy \\
\hline 13 & Butanal-2-methyl (CAS) & $\sqrt{ }$ & & $\sqrt{ }$ & $\sqrt{ }$ & almond, cocoa, fermented, hazelnut \\
\hline 14 & Hexanal (CAS) & $\sqrt{ }$ & $\sqrt{ }$ & $\sqrt{ }$ & $\sqrt{ }$ & green, fatty, leafy, fruity and woody \\
\hline 15 & (Furfural) 2-furancarboxaldehyde (CAS) & $\sqrt{ }$ & & $\sqrt{ }$ & & almond-like \\
\hline 16 & Eugenol & $\sqrt{ }$ & $\sqrt{ }$ & $\sqrt{ }$ & $\sqrt{ }$ & sweet, spicy, woody, phenolic, warm \\
\hline 17 & Nonanal & & $\sqrt{ }$ & & $\sqrt{ }$ & grassy, green, tea, vegetable \\
\hline 18 & Benzeneacetaldehyde & $\sqrt{ }$ & $\sqrt{ }$ & $\sqrt{ }$ & $\sqrt{ }$ & honey, floral, rose, chocolate, spicy \\
\hline 19 & 2-hexenal & $\sqrt{ }$ & $\sqrt{ }$ & $\sqrt{ }$ & $\sqrt{ }$ & $\begin{array}{l}\text { green, banana, aldehydic, fatty, herbal, spicy, } \\
\text { fresh }\end{array}$ \\
\hline 20 & Pentanal & $\sqrt{ }$ & & $\sqrt{ }$ & & almond, bitter, malt, oil, pungent \\
\hline 21 & Benzaldehyde & & $\sqrt{ }$ & $\sqrt{ }$ & $\sqrt{ }$ & $\begin{array}{l}\text { bitter almond, burnt sugar, cherry, green, } \\
\text { roasted pepper }\end{array}$ \\
\hline 22 & 6-methyl-5-hepten-2-one & $\sqrt{ }$ & & $\sqrt{ }$ & & citrus, pepper, strawberry \\
\hline 23 & 1-pentanol (CAS) & $\sqrt{ }$ & & & & mild, fusel-like, unpleasant \\
\hline 24 & Benzeneethanol (CAS) & $\sqrt{ }$ & $\sqrt{ }$ & $\sqrt{ }$ & $\sqrt{ }$ & floral, rose, burn, almond \\
\hline 25 & Pyridine & $\sqrt{ }$ & $\sqrt{ }$ & $\sqrt{ }$ & $\sqrt{ }$ & sour, putrid, fish-like \\
\hline 26 & Napthalene & $\sqrt{ }$ & $\sqrt{ }$ & $\sqrt{ }$ & $\sqrt{ }$ & floral, fruity \\
\hline
\end{tabular}




\begin{tabular}{|c|c|c|c|c|c|c|}
\hline 27 & $\begin{array}{l}\text { (Methyl Isopalmitate) Pentadecanoic } \\
\text { Acid,14methyl-, methyl ester }\end{array}$ & $\sqrt{ }$ & & & $\sqrt{ }$ & oily, waxy, fatty, oris \\
\hline 28 & Methyl salicilate & $\sqrt{ }$ & $\sqrt{ }$ & $\sqrt{ }$ & $\sqrt{ }$ & sweet, spicy, minty \\
\hline 29 & (guaiacol) Phenol,2-methoxy-(CAS) & $\sqrt{ }$ & $\sqrt{ }$ & $\sqrt{ }$ & $\sqrt{ }$ & phenolic, woody, smoky, spicy, eugenol-like \\
\hline 30 & $\begin{array}{l}\text { (BHT) Phenol,2,6-bis)1,1 } \\
\text { dimethylethenyl)-4-Methyl }\end{array}$ & $\sqrt{ }$ & & $\sqrt{ }$ & & slightly, phenolic, off-odor, off-flavor \\
\hline 31 & Alpha-ionone & $\sqrt{ }$ & & $\sqrt{ }$ & & woody, floral, nutty, berries \\
\hline 32 & 2-heptanone (CAS) & $\sqrt{ }$ & & & & $\begin{array}{l}\text { fruity, banana-like, nut, spicy, green, blue } \\
\text { cheese }\end{array}$ \\
\hline 33 & Beta-ionone & $\sqrt{ }$ & & $\sqrt{ }$ & $\sqrt{ }$ & woody, floral (rose-like), berries, cherry \\
\hline 34 & Acetyl pyrole & $\sqrt{ }$ & $\sqrt{ }$ & & $\sqrt{ }$ & $\begin{array}{l}\text { musty, nutty, walnut, bready, coumarinic, tea- } \\
\text { like }\end{array}$ \\
\hline 35 & $\begin{array}{l}\text { (3,5-cocoa pyrazine) Pyrazine, } 2 \text {-ethyl- } \\
\text { 3,5dimethyl-(CAS) }\end{array}$ & $\sqrt{ }$ & & $\sqrt{ }$ & & $\begin{array}{l}\text { nutty, roasted, coffee, cocoa, sweet, corn, } \\
\text { caramelic }\end{array}$ \\
\hline
\end{tabular}

The fermented samples of chlorophyll content will be lost due to maillard reaction, i.e. non-enzymatic browning which turns the color of coffee leaves to brown resembling a coffee bean. In addition, phenolic acids will decrease as temperature increases. With the presence of heat and oxygen, the phenolic compounds can be oxidized because the activity of polyphenol oxidase enzymes to form reactive ortho quinone radicals and can react further into amino compounds form a brown product (Reblova, 2012).

\subsection{Characteristics of Coffee Leaf Tea}

Table 2 shows that coffee leaf tea with different leaf age and pre-treatment factors shows a significant effect $(\mathrm{p}<0.05)$ on total phenol, caffeine, $\mathrm{pH}$ and color, but the presented temperatures only give a significant difference $(\mathrm{p}<0.05)$ to color.

\subsection{Total Phenolic Compound}

According to the Table 2, coffee leaf tea from old leaves has a higher total phenol value compared to tea from young leaves. According to Farhoosh et al. (2007), the old leaves of Robusta coffee have higher phenol levels. The high total content of polyphenols is due to the relatively soft texture and high moisture content in young leaves. The long sedimentation time provides greater heat penetration so that the polyphenol oxidase enzyme is inactive faster and results in less polyphenol damage (Osman et al., 2004). Nonfermented coffee leaf tea has a higher total phenol value than tea with fermentation process. According to Pou (2016) during the fermentation process the enzymes present on the leaves will be contact with air and begin to oxidize. Phenolic acids will decrease due to rising temperatures, heat and oxygen, so that the phenol compounds are oxidized because the enzyme activity of polyphenol oxidase forms a reactive radical orthosemiquinone and can react further into amino compounds.

\subsection{Caffeine}

According to Table 2, the percentage of caffeine in young coffee leaves tea is higher than old coffee leaf tea. According to Zheng and Ashihara (2004), caffeine contents in young leaves are higher than old leaves and gradually replaced by theacrine, which is converted into liberine as the dominant purine alkaloid in young leaves. The older coffee leaves contain smaller caffeine biosynthesis (Keya et al., 2003). The non-fermentation process produces coffee leaf tea with a higher caffeine percentage than the coffee leaf tea with a fermentation process. According to Mandal (Mandal, 2010), during caffeine fermentation other components such as acetone, furfural, ammonia, thrimrthylamine, formic acid and acetic acid evaporate and form. Ratanamarno 
and Surbkar (2017) suggest that the fermentation is one method to decrease caffeine in coffee. Increasing fermentation time, reducing caffeine levels in coffee. During the fermentation, caffeine is converted into uric acid, 7-methylxanthine and xanthine. (Todar, 2010).

\section{5. $\mathrm{pH}$}

According to Table 2 in the leaf age factor, the $\mathrm{pH}$ of steeped old coffee leaf tea is higher than steeped young coffee leaf tea. The young leaves contain higher moisture content and softer texture than the old leaves, so that the timber will provide greater heat penetration and result in easier polyphenol damage (Osman et al., 2004). According to Fulder (2004), the processing step results in oxidizing polyphenol component to theaflavin. If there is further oxidation, it will turn into thearubigin. If more thearubigin is formed, then the $\mathrm{pH}$ will decrease.

\subsection{Color}

The boiling or brewing processes oxidize the flavonoid compounds into phenol compounds, which later become quinone due to oxidize of heat. Further oxidation of the quinone will produce thearubigin which causes darker color in boiled tea water (Shahidi and Neczk, 2005) According to Reblova (2012), tea production requires heating, as the increase in temperature can lead to oxidize and browning marked color change in tea drinks. Temperature changes trigger the reactions of amino acids such as alanine, leucine, isoleucine, valine and tannins in the tea, releasing carbon dioxide molecules that will form the aldehyde complex that affects the brewing color.

\subsection{Correlation of Powders and Coffee Leaf Tea}

In general, coffee is consumed by the community in the form of powder that is brewed using hot water. Meanwhile, in the processing and brewing of tea, the tea should be brewed with the possible optimum concision to maximally utilize the content in the tea powder. Tea brewed with different water temperatures and durations will create different tastes. Tea brewed over makes more caffeine extracted. Even though polyphenols such as tannins require longer time to be extracted to give color and flavor, because too long brewing will leave a bad aftertaste (McAlpine and Ward, 2016). The extraction time refers to the amount of tea leaf time in contact with water and thus, the brewing time may occur. If the time is optimal, some compounds in the tea leaf will reach the point of equilibrium, meaning that the concentration of the compound in the leaves will be equal to the concentration of the compound present in the brewing water (Gerbely, 2016).

\subsection{Panelists' Response to Coffee Leaf Tea}

According to panelist's responses, coffee leaf tea has green smell as described in Figure 1. Green and similar terms such as grass have been used in many sensory analysis descriptions of various foods (Baldwin et al., 2004). Hexane is the compound most often associated with green characteristics such as cut grass (Buettner and Mestres, 2005) and herbs (Jordan et al., 2003). Alex Probyn in Grey (2013) mentions that coffee leaf tea has a very fresh taste, resembling fresh leaves like green tea, pungent and greenish.

Higher responses show that steeped old coffee leaf tea has a sweet flavored attribute than young coffee leaf tea, as described in Figure 2. According to Campbell et. al., (Campbell et al., 2006) carbohydrates in young leaves are still abundant in the form of starch, so the sweet taste is still low. Starch will be broken down into simple sugars such as glucose, fructose and sucrose during the aging process or maturation, so it becomes sweeter.

The bitter taste attribute is one significant difference, referring to Figure 2. The young leaves tea has a higher average intensity than old leaves. The higher bitter taste in younger leaves is thought to be due to the influence of caffeine content in younger leaves that are 
higher than in the old leaves. Ratanamarno and Subskar (2017) suggest that caffeine and phenol form the immune systems in leaves, causing bitterness. The caffeine content on young leaves is hinger than the old leaves. (Izzreen and Fadzelly, 2013).

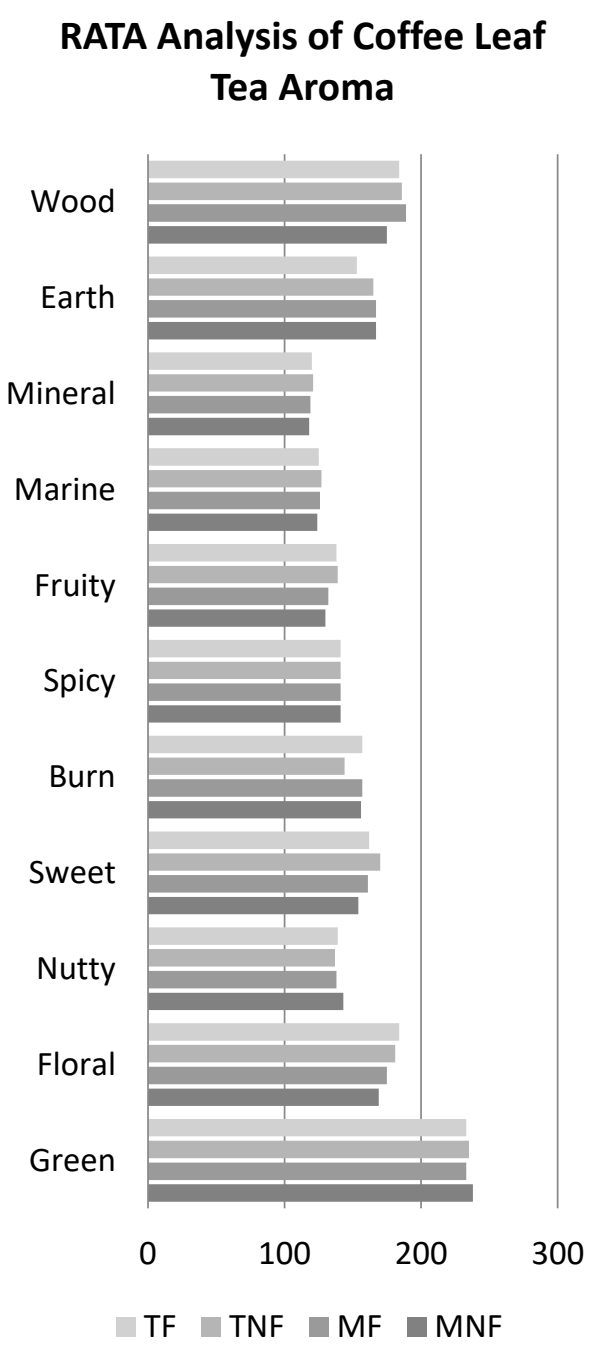

Figure 1. RATA analysis of coffee leaf tea aroma

Another distinct attribute is thesour taste . Young coffee leaf tea has a higher intensity than that in old coffee leaf tea, as described in Figure 2. The $\mathrm{pH}$ of young leaf tea is lower than that of old leaves. Lower $\mathrm{pH}$ indicates a more sour taste. According to Chan et. al. (2016), as the $\mathrm{pH}$ increases, the hydrogen ion concentration in the sample decreases, resulting in the release of hydrogen ions by phenolic compounds (antioxidants) in the sample. Furthermore, the decreasing $\mathrm{pH}$ decreases the antioxidant activity.
Earth and woody flavors in this study also have significantly different results, as described in Figure 2. The earth flavor in the tea is resulted from the 2-6-dimethylcyclohexanol and 2-isobutyl-3-methoxypirazin compounds (Lee and Chambers, 2006; Kumazawa and Masuda, 2002). Zecuppa (2017) explains that flavor wood resembles dry wood, wooden barrels, oak, dead wood, or cardboard. Woody flavors in coffee leaf tea can be caused by $\alpha$ Ionone and $\beta$-Ionone (Lee and Chambers, 2006). 


\section{RATA Analysis of Steeped Coffee}

Leaf Tea

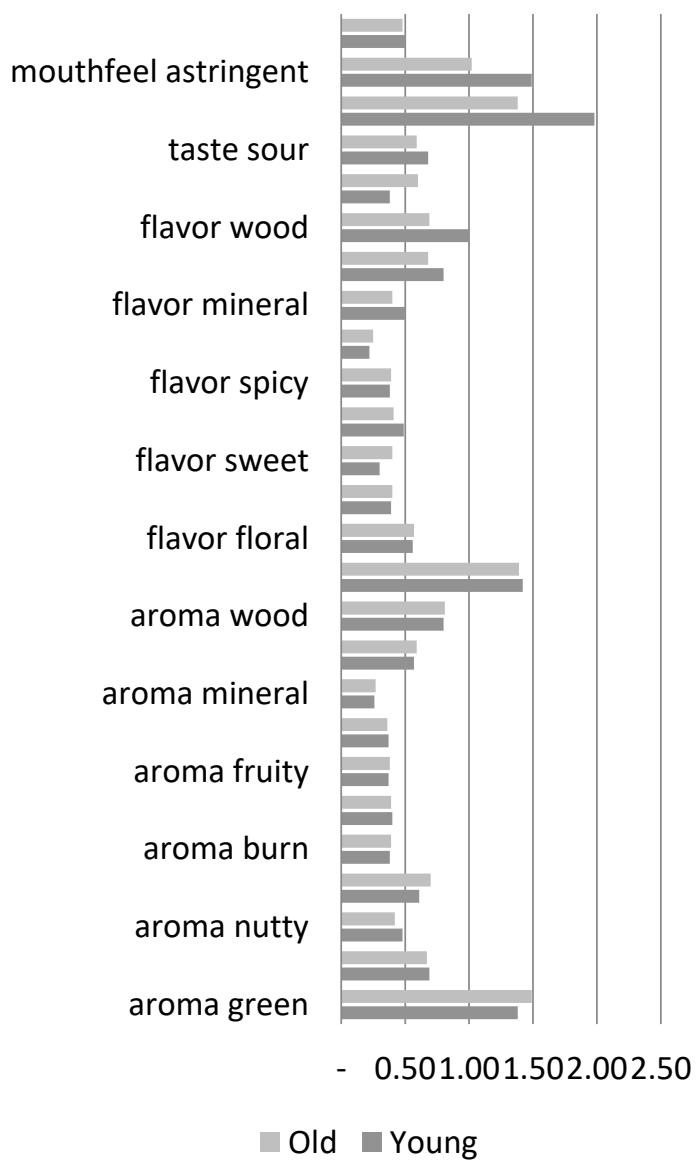

Figure 2. RATA analysis of steeped coffee leaf tea

\subsection{Volatile Compound on Coffee Leaf Tea}

The volatile compound is only about $0.01 \%$ of the total weight of the dry tea, but its contribution to overall tea quality is very important (Pripdeecech and Wongpomchai, 2013). In the coffee leaf tea analyzed by GCMS using SPME extraction, there were 71 volatile compounds in a non-fermented young leaf (MNF), 54 volatile compounds in fermented young leaf (MF), 62 volatile compounds in non-fermented old leaf (TNF), and 60 volatile compounds in the fermented of old leaf (TF). Large 35 volatile compounds presented in coffee leaf tea and aroma description can be seen in Table 3.

Volatile compounds of coffee leaf tea are dominated by green and floral fragrances that can be seen in Table 3. The predominant smell identified in coffee leaf tea is green in 11 out of 35 large compounds, such as 2-furanmethanol (CAS), 2-heptanol (CAS), 2-heptanol (CAS), safranal, beta-cyclocitral, hexanal (CAS), 4heptanal(Z)- (CAS), benzeneacetaldehyde, benzaldehyde, nonanal, and alpha-ionone. The "green" sensory characteristics are commonly used in describing the characteristics of various fresh vegetables, raw fruits, food products, and gentle fragrances. The term green and similar terms such as grass have been used in many sensory analysis descriptions of various foods (Balwon et al., 2004). Waltner-Law et. al. (2002) grouped volatile compounds found in green tea into the categories of green flavors, 
floral scents, baked and spicy scents, and offflavor (stale, burning smoke).

\subsection{Effect of Volatile Compounds on the Sensory Attributes of Coffee Leaf Tea}

Sensory attributes of coffee leaf tea are described in Figure 1. Aroma attribute consists of green, floral, spicy, fruity, marine, nutty, sweet, burn, minerals, earth, and woody. Meanwhile, the sensory attributes of steeped leaf coffee tea are categorized into aroma, taste, flavor, and mouthfeel. The flavor and aroma attributes consist of green, floral, spicy, fruity, marine, nutty, sweet, fire, minerals, earth, and woody. The taste attribute is detected using papilla on the tongue. The taste attribute consists of 3 attributes i.e. sweet, sour, and bitter. The mouthfeel attribute consists of astringent and oily, as described in Figure 2.

The sensory attribute of powder and coffee leaf tea is the green aroma, as described in Figure 1 and 2. This is due to the presence of hexenal, benzaldehyde, 2-hexenal, 2heptanone, alpha-ionone, and 2-hexen-1-ol. According to Kim et al., (2016), the smell of leaves in the tea is due to the presence of volatile components such as hexanal, benzadehyde, 2-hexenal, and 2-heptanone. The high intensity aroma sensory attributes of other coffee leaf tea are wood, floral, earth and sweet.

The highest intensity sensory attribute is thebitter taste, illustrated in Figure 2. Alek Probyn in Gray (2013) argues that coffee leaf tea has a bitter but acceptable character. Coffee leaves contain caffeine of $21.9 \mathrm{~g} / \mathrm{kg}$ per dry weight, epicatechin, mangiferin, isomangiferin $\mathrm{n}$, and some other phenolic components. Among the four basic tastes, bitterness is the most complex and least understood (2005). Other sensory attributes that also have high intensity are green, flavor green, and astringent. Alex Probyn in Gray (2013) also mentions that coffee leaf tea has a very fresh taste, resembling fresh leaf like green tea, pungent and greenish. The different processing and serving temperatures do not have a significant effect to the sensory attribute.

\section{Conclusions}

The results conclude that the coffee leaf tea has high intensity of green, wood, floral, earth and sweet. The steeping tea has characteristics of bitter taste, strong aroma and flavor of fresh leaves (green). The age of coffee leaves gives a significant influence on the 6 sensory attributes, namely the sweet taste, sour taste, bitter taste, sweet flavor, wood flavor, and earth flavor. Processing treatment and serving temperature do not give a significant effect on any sensory attributes.

\section{References}

Akira, O. (1977). Social change in West Sumatra village, 1908-1945. Thesis Doctor Canbera. The Australian University.

Ares, G.H., Bruzzone, L.,Vidal, R.S., Cadena, A., Giménez, A. and Pineau (2014). Evaluation of a rating-based variant of check-all-that-apply questions: rate-all- thatapply (RATA). Food Quality and Preference. 36, 87-95.

Baldwin, E.A., Scott, J.W., Bai, J. (2004). Sensory and chemical flavor analyses of tomato genotype grown in Florida during three different growing seasons in multiple years. Jurnal of the American Society for Horticultural Science. 140(5), 490-503.

Bhara, M. (2004). The influence of graded coffee dosage per oral 30 days to the histopathology of the wistar mouse histopathology, Semarang: FK UNS Thesis.

Booth, A., O'Malley, W., Weidemann, A. 1988. Economic history of Indonesia. Jakarta : LP3ES. 157-160. Transleted by Mien Joebhaar.

Bradley, R.L., Vanderwarn, M.A. (2001) Determination of moisture in cheese and cheese products. Journal of Association of 
Official Agricultural Chemists International. 84, 570-592.

Buettner, A. Mestres, M. (2005). Investigation of the retronasal perception of strawberry aroma aftersmell depending on matrix composition. Journal of Agricultural and Food Chemistry. 53, 1661-1669.

Calvert, R. Vohra, S. Ferguson, M., Wiesenfeld, P. (2015). A beating heart cell model to predict cardiotoxicity: effects of the dietary supplement ingredients higenamine, phenylethylamine, ephedrine and caffeine. Journal Food and Chemical Toxicology. 78, 207-213.

Campanha, F.G., Dias, R.C.E.D., Benassi, M.T. 2009. Descrimination of coffee species using kahweol and cafestol: effects of roasting and of defects. Coffee Science, Lavras. 5(1), 87-96.

Campbell, N.A., Reece, J.B., Mitchell, L.G. (2006). Biology. Concepts and Connections. 5th Edn. Addison Wesley Longman Inc. 118.

Chan, Y.M., Cheng, N.K., Nigam, P.S. and Owusu-Apenten, R.K.O. (2016). Effect of $\mathrm{pH}$ on the radical wuenching capacity of tea infusions using the ABTS assay. Journal of Applied Life Science International. 6(2), 1-8.

Christian, G.D. (1994). Analytical Chemistry, John Wiley, 5th Edn, 505.

Farhoosh, R., Golmovahled, G.A., Khodaparast, M. H. (2007). Antioxidant activity of various extracts of old tea leaves and black tea wastes (Camellia sinensis L.), Journal of Food Chemistry. 100, 231-236.

Fulder, S. (2004). Application of green tea. 2004, Prestasi Pustaka Publisher. Jakarta. Translated by T.R. Wilujeng. (2009), 29.

Gerbely, T. (2016). Tea: A Users Guide.

Gray, R. (2013). Tea made from coffee leaves found to beneficial for health. http://www.telegraph.co.uk/news/science/sci ence-news/9797675/Tea made-from-coffee- leaves-found-to-beneficial-for-health. html. (Accesseds: April 2017).

Hatakka, A. (2001). Biodegradation of lignin. In: Hofricher, M. and Steinbuchel, A., Eds., Biopolymers, Vol. 1: lignin, humic substances and coal, Weinheim: Wiley VCH. 129- 180.Hoeger, W.L. Turner, Hafen, B. (2001). Wellness: guidelines for a healthy lifestyle, 3rd Edn. Brooks Cole.

Izzreen, N.Q., Fadzelly, M. (2013). Phytochemical and antioxidant properties of different part of Camellia sinensis leaves from Sabah tea plantation in Sabah, Malaysia. International Food Research Journal. 20(1), 307-312.

Jonathan, H.C., Barledi, C.F., Joyner, G. (2009). Coffee growing in the Florida home landscape. U.S. department of agriculture, Thesis. UF/IFAS Extension Service, University of Florida.

Jordan, M.J., Margaria, C.A., Shaw, P.E., Goodner, K.L. (2003). Volatile components and aroma active compounds in aqueous essence and fresh pink guava fruit puree (Psidium guajava L.) by GC-MS and multidimensional GC/GC-O”. Journal of Agricultural and Food Chemistry. 51, 14211426.

Keya, C.A., Crozier, A., Ashihara, H. (2003). Inhibition of caffeine biosynthesis in tea (Camellia sinensis) and coffee (Coffe arabica) plants by ribavirin. FEBS Letters, 554, 473- 477.

Khan, N., Mukhtar, H. (2007). Tea polyphenols for health promotion. Life Science. 81(7), 519-553.

Kim, Y., Lee, K.G., Kim, M.K. (2016). Volatile and non-volatile compounds in green tea affected in harvesting time and their correlation to consumer preference. Journal of Food Science and Technology. 53(10), 3735-3743. 
Kumazawa, K., Masuda, H. (2002). Identification of potent odorants in different green tea varieties using flavor dilution technique. Journal of Agricultural and Food Chemistry, 50(20), 5660-5663.

Lee, J., Chambers, D.H. (2006). A lexicon for flavor descriptive analysis of green tea. Journal of Sensory Study, 22, 256-272.

Lee, J.D., Chambers, Chambers, E. (2013). Sensory and instrumental flavor changes in green tea brewed multiple times. Foods, 2(4), 554-571.

Mandal, A. (2010). Caffeine occurrence. http://www.newsmedical.net/health/caffeine occurrence.aspx. (Accessed: May 2017).

McAlpine, M.D., Ward, W.E. (2016). Influence of steep time on polyphenol content and antioxidant capacity of black, green, rooibos and herbal teas. Journal Beverages, 2(17), $1-12$.

Osman, H., Nasarudin, R., Lee. S.L. (2004). Extracts of cacao (Theobroma cacao L.) leaves and their antioxidant potential. Food Chemistry. 86, 41-46.

Pal, S., Ghosh, D., Saha, C., Dey, S.K. (2012). Total polyphenol content, antioxidant activity and lipid peroxidation inhibition efficacy of branded tea (Camellia sinensis) available in India. International Journal of Tea Science. 13-20.

Pou, K.R.J. 2016. Fermentation: The Key Step in the Processing of Black Tea. Journal of Biosystems Engineering, 41(2), 85-92.

Pripdeecech, P., Wongpornchai, S. (2013). Odor and flavor volatiles of different types of tea. In: Preedy V, Elsevier BV (eds) Tea in Health and Disease Prevention. 1st ed, Amsterdam, Netherlands, 307-322.

Ratanamarno, S., Surbkar, S. (2017). Caffeine and catechins in fresh coffee leaf (Coffea arabica) and coffee leaf tea. Maejo International Journal of Science and Technology. 11(03), 157-160.
Reblova, Z. (2012). Effect of temperature on the antioxidant activity of phenolic acids. Czech Academy of Agricultural Science. 30, 171-175.

Shahidi, F., Naczk, M. (2005). Phenolics in food and nutraceuticals. RC Press LLC, New York.

Todar, K. (2010). Nutrition and growth of bacteria Departement of Bacteriology, University of Wisconsin, http:// textbookofbacteriology.net/ nutgro_ 2.html. (Accessed: April 2016).

Waltner-Law, M.E., Wang, X.L., Law, B.K., Hall, R.K., Nawano, M., Granner, D.K. (2002). Epigallocatecin gallate, a constituent of green tea, represses hepatic glucose production. The Journal of Biological Chemistry. 277, 34933-34940.

WBCM and ICO. (2017). World Coffee Consumption.http://www.ico.org/prices/new consumption-table. pdf (Accessed : September 2017).

Yitayal, A.A., Achame, H.A. (2015). Sociocultural practice on coffee made from mixtures of coffee leaf and spices. International Multidisciplinary E-Journal (IMEJ). 3(6), 36-45.

Yitayal, A.A., Titalun, R.D. (2017). Nutritional value of coffee made from a mixture of coffee leaf and spices used in Ethiophia. Journal of Nutrition and Food Sciences. 7(4).

Zecuppa. (2017). Coffee terms - cupping and tasting.http://www.zecuppa.com/coffeeterms -cupping-tasting.htm. (Accessed: May 2017).

Zheng, Z.Q., Ashihara, H. (2004). Distribution, biosynthesis, and function of purine and piridine alkaloids in coffea arabica seedlings. Plant Science, 166, 807-813. 